\title{
Determinants of mortality in patients with traumatic brain injury
}

\author{
Travmatik beyin hasarı olan hastalarda mortalite belirleyicileri
}

\section{Soheil SAADAT, Hesam AKBARI, Reza KHORRAMIROUZ, Roza MOFID, Vafa RAHIMI-MOVAGHAR}

\section{BACKGROUND}

We aimed to determine factors associated with mortality rates in patients with traumatic brain injury (TBI).

\section{METHODS}

Registered data of a national trauma project conducted in eight major cities in Iran during a five-year period were used. Patients with a TBI were identified and both univariate and multivariate analyses were performed.

\section{RESULTS}

2274 brain-injured patients including 1794 males $(78.9 \%)$ were identified. The mean age of the patients was $30.1 \pm$ 19.11 years. The age of 345 patients was less than 12 , while 137 patients were older than 65.383 patients $(16.9 \%)$ died as a result of their injury. Univariate analysis showed a significant association between mortality and the following factors: age, sex, Glasgow Coma Scale (GCS), Injury Severity Score (ISS), systolic, diastolic and mean arterial blood pressure $(B P)$, and respiratory rate $(R R)(p<0.05)$. The logistic regression analysis revealed a statistically significant association between death and age (odds ratio $[\mathrm{OR}]=1.04)$, GCS $(\mathrm{OR}=0.59)$, ISS $(\mathrm{OR}=1.03)$, mean arterial $\mathrm{BP}(\mathrm{OR}=0.71)$, and $\mathrm{RR}(\mathrm{OR}=0.82)$ one-half hour after hospital arrival.

\section{CONCLUSION}

Our results demonstrated that age, GCS, ISS, BP, and RR as prognostic factors in patients with TBI indicate those that need special care during the initial management in the emergency department.

Key Words: Mortality; outcome; prognosis; traumatic brain injury.

\section{$A M A C ̧$}

Travmatik beyin hasarı (TBH) bulunan hastalarda mortalite ile ilişkili faktörleri belirlemeyi amaçladık.

\section{GEREÇ VE YÖNTEM}

İran'da beş y1llık bir periyot boyunca 8 büyük kentte yürütülen ulusal travma projesinin veri kayıtları kullanıldı. TBH'li hastalar belirlendi, tek değişkenli ve çok değişkenli analizler yapıldı.

\section{BULGULAR}

Beyin yaralanması geçirmiş 2274 hasta kaydına ulaşıldı

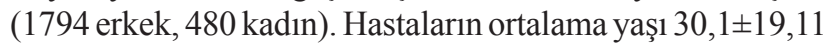
yı1 idi, 345 hastanın yaşı 12'den küçük, 137 hastanın yaşı 65 'den büyüktü. Hastaların 383'ü $(\% 16,9)$ bir yaralanmaya bağlı ölmüştü. Tek değişkenli analiz; mortalite ile şu faktörler arasında anlamlı bir birliktelik bulunduğunu gösterdi: Yaş, cinsiyet, Glasgow koma skoru (GKS), yaralanma ciddiyeti skoru (YCS), sistolik, diyastolik ve ortalama arteriyel kan basıncı (KB) ve solunum oranı (SO) $(\mathrm{p}<0,05)$. Lojistik regresyon analizi, hastaneye varıştan yarım saat sonrasından itibaren ölüm ile aşağıdakiler arasında anlamlı bir ilişki bulunduğunu gösterdi: Yaş $(\mathrm{OR}=1,04), \mathrm{GKS}(\mathrm{OR}=0,59)$, YCS $(\mathrm{OR}=1,03)$, ortalama arteriyel $\mathrm{KB}(\mathrm{OR}=0,71)$ ve $\mathrm{SO}$ $(\mathrm{OR}=0,82)$.

\section{SONUÇ}

Bizim sonuçlarımız, acil servis bölümünün ilk tedavisi süresince özel bakım gerektiren TBH'li hastalarda prognostik faktörlerin yaş, GKÖ, YCS, KB ve SO olduğunu göstermiştir.

Anahtar Sözcükler: Mortalite; sonuç; prognoz; travmatik beyin hasar1.
Sina Trauma and Surgery Research Center,

Student's Scientific Research Center (SSRC) Tehran University Medical Sciences, Tehran, Iran.
Tahran Üniversitesi Tip Bilimleri, Öğrenci Bilimsel Araştırma Merkezi (ÖBAM) Sina Travma ve Cerrahi Araştırma Merkezi, Tahran, İran.

Correspondence (İletişim): Vafa Rahimi-Movaghar, M.D. Tehran University Medical Sciences, Sina Trauma and Surgery Research Center, Sina Hospital, Hassan-Abad Square, Imam Khomeini Ave., Tehran, 11365-3876, Iran. 
Traumatic brain injury (TBI) is a complex injury with a broad spectrum of symptoms and disabilities caused by a sudden trauma to the brain or an object piercing the brain tissue. Each year, 1.5 million Americans suffer from TBI. Fifty thousand people die as a result of these injuries. ${ }^{[1]}$ The rate of TBI incidence is higher in children and the elderly, but the mortality rate is higher in people older than 60 years. ${ }^{[2]}$ The incidence of TBI is higher in males, but in the same condition of severity, poorer prognosis has been reported for females. ${ }^{[3]}$ These figures/statistics show the importance of understanding the determining factors of TBI outcome. According to several studies, some factors, including older age, female gender, low Glasgow Coma Scale (GCS), high Injury Severity Score (ISS), lower respiratory rate (RR), pulse rate (PR), hypotension, hypoxia, hyperthermia, and alcohol consumption, have an association with TBI outcome.

In this study, the factors determinant of the Glasgow Outcome Scale (GOS) in patients with TBI admitted to the emergency department have been evaluated.

\section{MATERIALS AND METHODS}

This is a retrospective cross-sectional study performed using the data from Iran's national trauma registry database from August 1999 to February 2004. The data were collected from the target hospitals in eight major cities of Iran. The data of every patient admitted in these hospitals due to mild, moderate or severe trauma and who had a hospital stay of more than 24 hours were registered in the database. The data extracted from the original database included the general characteristics of the patients, like age, sex, GCS, vital signs including systolic (SBP), diastolic (DBP) and mean arterial blood pressure (MBP), RR, PR, ISS, presence of TBI, Abbreviated Injury Scale (AIS), and final disposition/outcome. These parameters were evaluated one-half hour after the patient's arrival to the emergency room by a general physician or a trained nurse. The data were gathered by the general physicians. Further data collection was made and reported by the same doctors. The type of TBI and the mechanism of accidents were coded according to the International Classification of Diseases, 9th revision (ICD-9). AIS scores were used to classify injury severity and were assigned to all injuries (ICD-9-CM 800-904 and 910-959) noted in the diagnostic record of cases hospitalized with TBI. ISS was calculated from the sum of squares of the highest AIS score in the three most severely injured body regions.

The statistical analyses included Student's t test to compare means and chi-square testing of frequency data, where appropriate. The significance level was set at 0.05 . The statistical analyses of the data were done using SPSS 15.0 (SPSS Inc, Illinois, USA). The logistic regression model for prediction of death in patients with TBI was based on their age, sex, ISS, GCS, MBP, $\mathrm{PR}$, and RR at the time of admission into the emergency department.

\section{RESULTS}

Of 2274 patients with a TBI, $480(21.1 \%)$ were females and $1794(78.9 \%)$ were males. The mean age of the patients was $30.1 \pm 19.11$ years and it was similar between genders (Table 1). The ISS and GCS of the male patients were higher and lower, respectively, than in females, and the difference was statistically significant (Table 1).

The GCS score of the patients ranged from $3(4 \%)$ to $14(30 \%)$ (Fig. 1). 383 patients $(16.9 \%)$ died as a result of their injury. Mortality was higher in males $(18.2 \%)$ compared to females $(12.2 \%)$, and the difference was statistically significant $(\mathrm{p}<0.01)$. The age and ISS of the patients who died due to injury was higher, while their GCS, SBP, DBP, and RR were lower than the patients discharged alive from the hospital (Table 2 ). The relationship between the death rates of the patients with a TBI and their vital signs in the emergen-

Table 1. Characteristics of the patients according to gender

\begin{tabular}{lccccccc}
\hline & \multicolumn{2}{c}{ Total } & \multicolumn{2}{c}{ Male } & \multicolumn{2}{c}{ Female } & \multirow{2}{*}{$p$} \\
\cline { 2 - 6 } & Mean & SD & Mean & SD & Mean & SD & \\
\hline Age & 30.1 & 19.11 & 29.9 & 18.29 & 30.8 & 21.90 & $>0.05$ \\
GCS & 11.0 & 3.38 & 10.8 & 3.44 & 11.6 & 3.06 & $<0.001$ \\
SBP & 110.8 & 19.92 & 111.2 & 19.29 & 109.2 & 22.10 & $>0.05$ \\
DBP & 68.9 & 12.48 & 69.3 & 12.05 & 67.4 & 13.88 & $<0.01$ \\
MBP & 82.9 & 14.16 & 83.3 & 13.66 & 81.3 & 15.83 & $<0.05$ \\
RR & 18.2 & 4.34 & 18.3 & 4.35 & 18.0 & 4.29 & $>0.05$ \\
PR & 86.2 & 14.30 & 85.7 & 14.28 & 87.8 & 14.28 & $<0.01$ \\
ISS & 17.1 & 16.02 & 17.8 & 16.57 & 14.2 & 13.34 & $<0.001$ \\
n (\%) & $2274(100 \%)$ & $1794(78.9 \%)$ & $480(21.1 \%)$ & \\
\hline
\end{tabular}

GCS: Glasgow Coma Scale; SBP, DBP, MBP: Systolic, diastolic and mean arterial blood pressure; RR: Respiratory rate; PR: Pulse rate; ISS: Injury Severity Score. 
cy department are displayed in Figures 2-5. Figure 2 demonstrates that BPs higher than 135 and lower than 90 were associated with a poor prognosis in patients with TBI. DBP of less than 50 was associated with

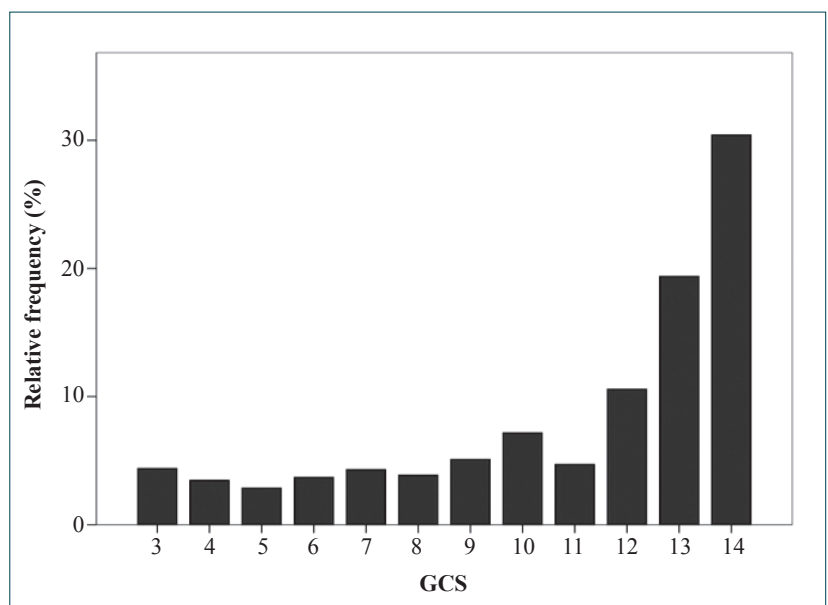

Fig. 1. Distribution of Glasgow Coma Scale (GCS) in headinjured patients.

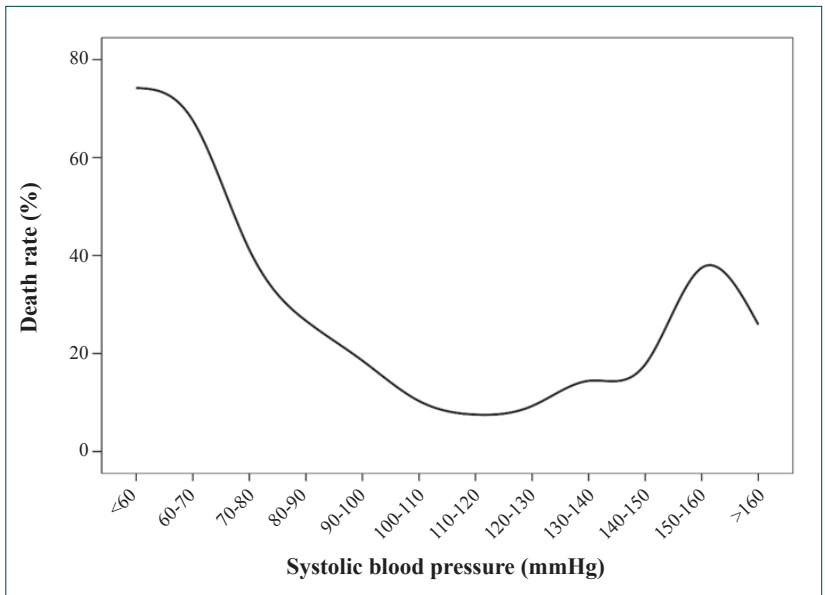

Fig. 2. Death rate according to systolic blood pressure (SBP) of head -injured patients.

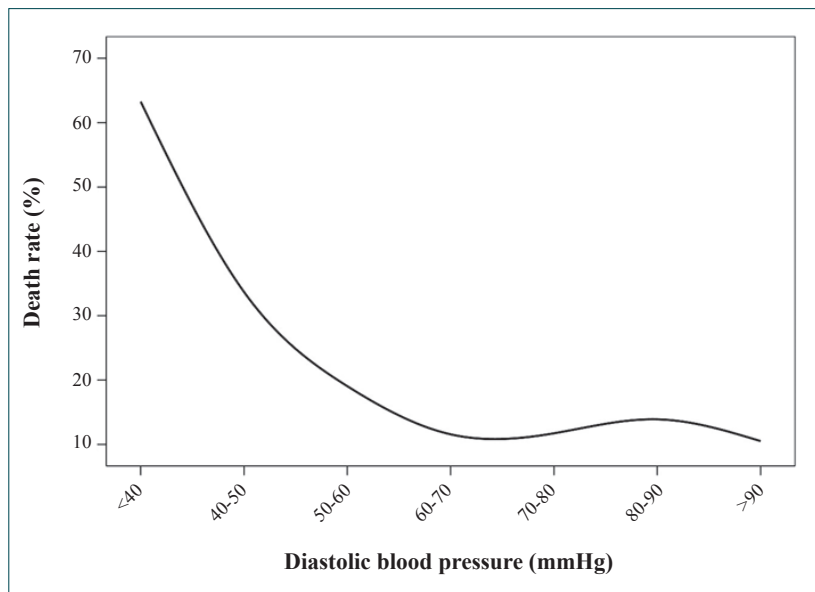

Fig. 3. Death rate according to diastolic blood pressure (DBP). higher death rates (Fig. 3). RRs higher than 25 and lower than 10 increased mortality rates (Fig. 4). PRs lower than 70 and higher than 120 had a significant effect on mortality in patients with TBI (Fig. 5). However, the mean PR in both alive and exitus patients was almost equal (Table 2). The death rates were inversely associated with GCS at admission (Figure 6).

The logistic regression analysis revealed a statistically significant association between death and age, GCS, ISS, MBP, and RR (Table 3).

\section{DISCUSSION}

Our study demonstrated that there was a statistically significant association between death and older age, lower RR, hypotension, low GCS, and high ISS levels in patients with TBI. Thus, most of the data from the western literature concerning TBI are confirmed by this work.

Trauma and TBI are more common in males than females. This study also included more males than females. Male patients arrived in worse conditions with lower GCS and higher ISS levels. When both genders were evaluated in similar conditions, the logistic regression model did not show a significant difference in mortality between males and females. There are controversies in the literature about the role of gender differences in outcome after TBI. It has been shown that a better outcome in females might be due to the neuroprotective effect of progesterone. ${ }^{[4]}$ However, several other studies pointed out that females have a lower six-month survival and a poorer prognosis than males. ${ }^{[3,5]}$ Another study showed that females have a poorer prognosis in similar injury severity. ${ }^{[6]}$

Similar to our study, it has been shown that TBI is associated with poorer prognosis in the elderly, es-

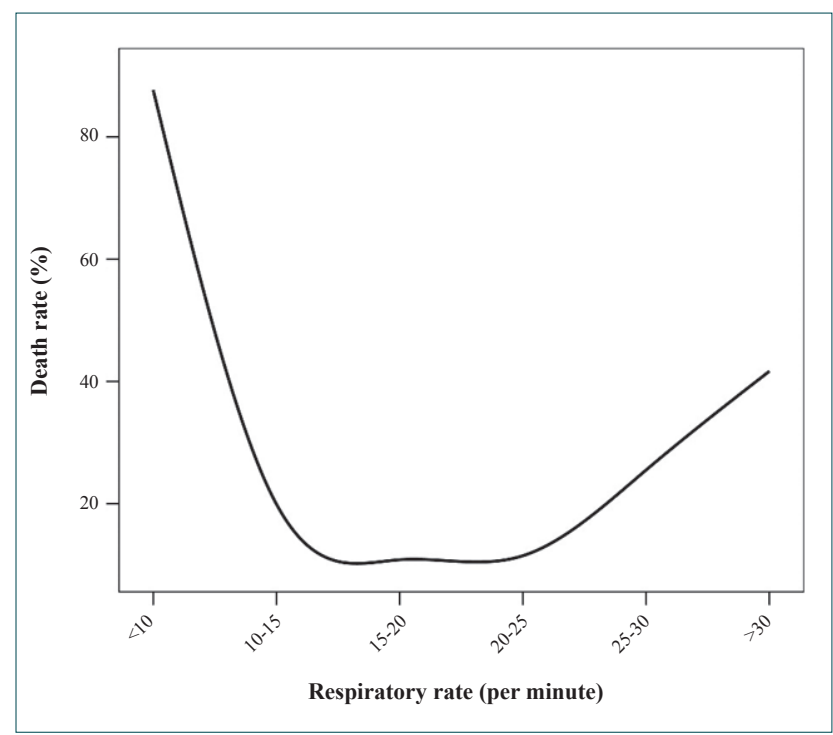

Fig. 4. Death rate according to respiratory rate (RR). 
Table 2. Comparison of age, Glasgow Coma Scale (GCS) and vital signs in alive and exitus headinjured patients

\begin{tabular}{lccccc}
\hline & \multicolumn{2}{c}{ Alive } & \multicolumn{2}{c}{ Exitus } & $\mathrm{p}$ \\
\cline { 2 - 5 } & Mean & SD & Mean & SD & \\
\hline Age & 28.7 & 18.46 & 36.8 & 20.62 & $<0.001$ \\
GCS & 12.0 & 2.46 & 6.2 & 3.08 & $<0.001$ \\
SBP & 112.4 & 17.75 & 102.7 & 26.87 & $<0.001$ \\
DBP & 70.1 & 11.46 & 63.0 & 15.33 & $<0.001$ \\
MBP & 84.2 & 12.76 & 76.2 & 18.25 & $<0.001$ \\
RR & 18.5 & 3.95 & 16.7 & 5.73 & $<0.001$ \\
PR & 86.3 & 12.72 & 85.6 & 20.47 & $>0.05$ \\
ISS & 13.7 & 11.96 & 33.0 & 21.96 & $<0.001$ \\
\hline
\end{tabular}

SBP, DBP, MBP: Systolic, diastolic and mean arterial blood pressure; RR: Respiratory rate; PR: Pulse rate; ISS: Injury Severity Score.

pecially in those above $60 .^{[7-9]}$ The age of patients is somewhat different, particularly regarding the very low incidence of TBI in the older age group (only $6 \%$ are older than 65 years). This low percentage of elderly patients might be due to the younger aged population in developing countries. Moreover, recent data suggest that among the 250,000 hospitalized for TBI in the United States, around $22 \%$ die. Notwithstanding the greater number of American hospitals, in this Iranian population, the mortality is less, at only $17 \%$ $(p<0.001)$. This might have something to do either with the cause of the TBI or with a major selection of patients (i.e., a larger group of patients die before reaching the hospital). On the other hand, there is no association between TBI outcome and age lower than 40 years. ${ }^{[10]}$

As far as we found in the literature, all authors agree with a reverse association between GCS and TBI outcome.$^{[8,11]}$ ISS is another factor that has a direct

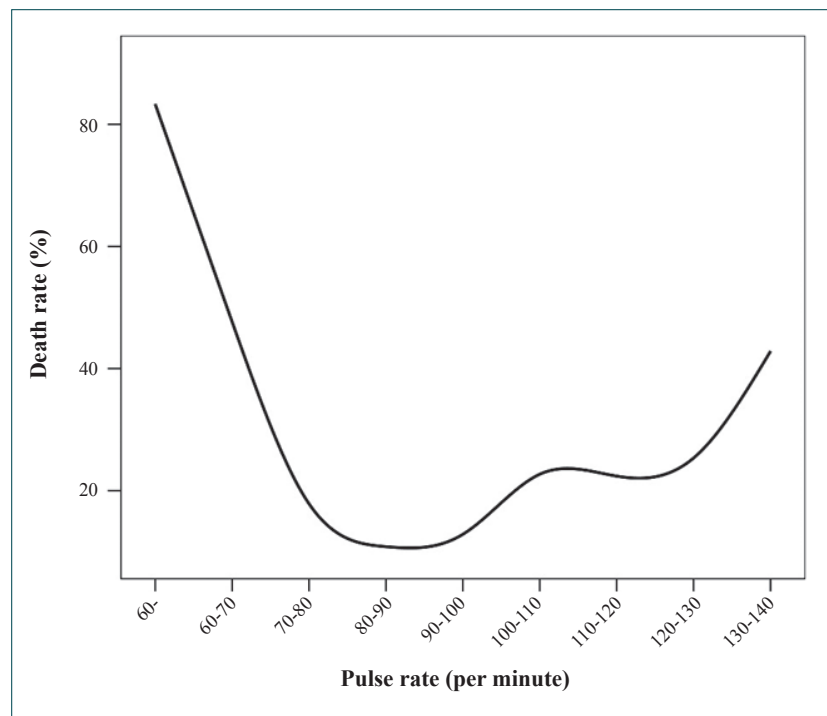

Fig. 5. Death rate according to pulse rate (PR).
Table 3. Logistic regression model for prediction of death in patients with a traumatic brain injury based on their age, ISS, GCS, mean blood pressure, and RR at admission into the emergency department (Nagelkerke R Square: 0.63)

\begin{tabular}{lcccc}
\hline Variable & B & S.E. & Sig. & OR \\
\hline Age & .040 & .005 & .000 & 1.041 \\
ISS & .030 & .005 & .000 & 1.031 \\
GCS & -.520 & .030 & .000 & .595 \\
MBP & -.335 & .072 & .000 & .716 \\
RR & -.197 & .095 & .038 & .821 \\
Model constant & 3.075 & .452 & .000 & 21.647 \\
\hline
\end{tabular}

ISS: Injury Severity Score; GCS: Glasgow Coma Scale; MBP: Mean blood pressure; RR: Respiratory rate.

relation with TBI. High ISS levels increase mortality rates in patients with TBI. The effects of GCS and ISS have been considered for a better prediction in TBI. ${ }^{[12]}$

Hypotension following TBI is known as a significant secondary insult that is associated with adverse outcome. There is a U-shaped relationship between SBP and TBI outcome. ${ }^{[13]}$ The best outcomes were observed for values of SBP between 135 and $90 \mathrm{mmHg}$. Both lower and higher levels of SBP were associated with poorer outcome. The present guidelines for the management of BP in TBI focus on the prevention of $\mathrm{SBP}<90 \mathrm{mmHg}$.

Traumatic brain injury (TBI) causes dysautonomia that is manifested as fluctuations in PR and RR. ${ }^{[14,15]}$ Dysautonomia arises in about $10 \%$ of patients surviving severe TBI, which is more likely to have poorer outcome. ${ }^{[14]}$ Both increase and decrease in RR out of the normal range is associated with a poor outcome in patients with TBI. There are similar findings about the association between PR and mortality in patients with

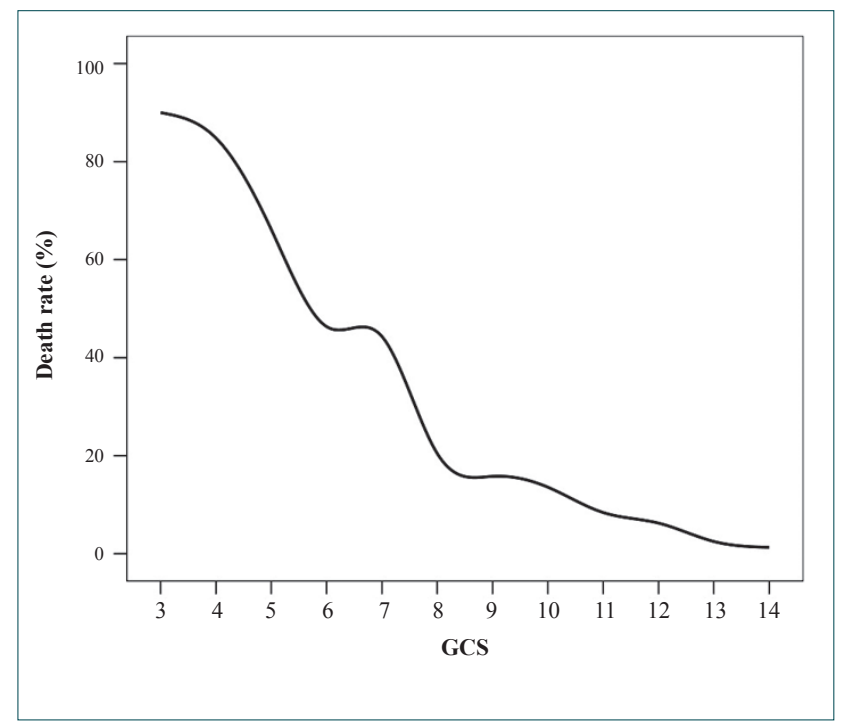

Fig. 6. Death rate according to Glasgow Coma Scale (GCS). 
TBI ${ }^{[15,16]}$ Heart rate variability might be a predictor of pending brain death and a useful addition for predicting the outcome of patients with severe head injury ${ }^{[15]}$ even at 12 hours. ${ }^{[16]}$

Causes of TBI were not mentioned, because there was no association between these factors and mortality in patients with TBI in our study. However, the most common mechanism of trauma was motor-vehicle crash $(62.5 \%)$, followed by fall $(23.8 \%){ }^{[17]}$

\section{Limitations of the Study}

Hypoxia, hyperthermia and alcohol consumption were significant risk factors in other studies. ${ }^{[18-}$ ${ }^{23]}$ However, we did not point to these factors in our study. Although it has been shown that bradypnea had an unfavorable prognosis in TBI, considering arterial blood gases could add valuable information in analyzing respiratory function. Concerning the unfavorable outcome in the elderly, the study does not indicate the cause of the outcome as being due to accompanying pathologies or secondary factors of brain damage during intensive therapy.

The patients underwent different management before arrival to the emergency department. The interval before admission was also different in the injured patients. Patients hospitalized for less than 24 hours were not considered in our study. A brain computed tomography (CT) scan was performed in all patients. There were some operative procedures performed, but the effects on outcome were not registered. Intracranial pressure measurement was not performed in the patients. While we know the number of patients who died, we do not have GOS of the patients at six months after injury. Finally, there were diverse associated injuries in the study. The injury severity was only evaluated by the ISS. Although all the cases referred to the emergency department at any hour were included in the study, follow-up was not complete in those patients who were transferred to private hospitals.

In conclusion, our results emphasize the role of the following prognostic factors in patients with TBI: bradypnea, systemic hypotension, ISS, GCS, and old age, which are independent risk factors and predictors of mortality. Special care is recommended for patients with these risk factors during the initial management in the emergency department.

\section{Acknowledgement}

The database was provided by Sina Trauma and Surgery Research Center. The authors thank Mrs. Bita Pourmand for her careful editing of the manuscript.

\section{Disclaimer}

The authors received no funding for this clinical research.

\section{REFERENCES}

1. Thurman DJ, Alverson C, Dunn KA, Guerrero J, Sniezek JE. Traumatic brain injury in the United States: A public health perspective. J Head Trauma Rehabil 1999;14:602-15.

2. Harris C, DiRusso S, Sullivan T, Benzil DL. Mortality risk after head injury increases at 30 years. J Am Coll Surg 2003;197:711-6.

3. Farace E, Alves WM. Do women fare worse? A metaanalysis of gender differences in outcome after traumatic brain injury. Neurosurg Focus 2000;8:6.

4. Groswasser Z, Cohen M, Keren O. Female TBI patients recover better than males. Brain Inj 1998;12:805-8.

5. Ponsford JL, Myles PS, Cooper DJ, Mcdermott FT, Murray $\mathrm{LJ}$, Laidlaw $\mathrm{J}$, et al. Gender differences in outcome in patients with hypotension and severe traumatic brain injury. Injury 2008;39:67-76.

6. Moppett IK. Traumatic brain injury: assessment, resuscitation and early management. Br J Anaesth 2007;99:18-31.

7. Hukkelhoven CW, Steyerberg EW, Rampen AJ, Farace E, Habbema JD, Marshall LF, et al. Patient age and outcome following severe traumatic brain injury: an analysis of 5600 patients. J Neurosurg 2003;99:666-73.

8. Jiang JY, Gao GY, Li WP, Yu MK, Zhu C. Early indicators of prognosis in 846 cases of severe traumatic brain injury. $\mathrm{J}$ Neurotrauma. 2002;19:869-74.

9. Mosenthal AC, Lavery RF, Addis M, Kaul S, Ross S, Marburger R, et al. Isolated traumatic brain injury: age is an independent predictor of mortality and early outcome. J Trauma 2002;52:907-11.

10. MRC CRASH Trial Collaborators, Perel P, Arango M, Clayton T, Edwards P, Komolafe E, et al. Predicting outcome after traumatic brain injury: practical prognostic models based on large cohort of international patients. BMJ 2008;336:425-9.

11. McNett M. A review of the predictive ability of Glasgow Coma Scale scores in head-injured patients. J Neurosci Nurs 2007;39:68-75.

12. Foreman BP, Caesar RR, Parks J, Madden C, Gentilello LM, Shafi S, et al. Usefulness of the abbreviated injury score and the injury severity score in comparison to the Glasgow Coma Scale in predicting outcome after traumatic brain injury. J Trauma 2007;62:946-50.

13. Butcher I, Maas AI, Lu J, Marmarou A, Murray GD, Mushkudiani NA, et al. Prognostic value of admission blood pressure in traumatic brain injury: results from the IMPACT study. J Neurotrauma 2007;24:294-302.

14.Hendricks HT, Heeren AH, Vos PE. Dysautonomia after severe traumatic brain injury. Eur J Neurol 2010;17:11727.

15. Rapenne T, Moreau D, Lenfant F, Vernet M, Boggio V, Cottin $Y$, et al. Could heart rate variability predict outcome in patients with severe head injury? A pilot study. J Neurosurg Anesthesiol 2001;13:260-8.

16. Norris PR, Morris JA Jr, Ozdas A, Grogan EL, Williams AE. Heart rate variability predicts trauma patient outcome as early as $12 \mathrm{~h}$ : implications for military and civilian triage. J Surg Res 2005;129:122-8.

17. Saadat S, Rashidi-Ranjbar N, Rasouli MR, RahimiMovaghar V. Pattern of skull fracture in Iran: report of the Iran National Trauma Project. Ulus Travma Acil Cerrahi Derg 2011;17:149-51.

18. De Guise E, Leblanc J, Dagher J, Lamoureux J, Jishi AA, Maleki M, Early outcome in patients with traumatic brain injury, pre-injury alcohol abuse and intoxication at time of 
injury. Brain Inj 2009;23:853-65.

19. Marion DW, Penrod LE, Kelsey SF, Obrist WD, Kochanek PM, Palmer AM, et al. Treatment of traumatic brain injury with moderate hypothermia. N Engl J Med 1997;336:5406.

20. McHugh GS, Engel DC, Butcher I, Steyerberg EW, Lu J, Mushkudiani N, et al. Prognostic value of secondary insults in traumatic brain injury: results from the IMPACT study. J Neurotrauma 2007;24:287-93.

21. Shandro JR, Rivara FP, Wang J, Jurkovich GJ, Nathens AB,
MacKenzie EJ. Alcohol and risk of mortality in patients with traumatic brain injury. J Trauma 2009;66:1584-90.

22. Stiefel MF, Spiotta A, Gracias VH, Garuffe AM, Guillamondegui $\mathrm{O}$, Maloney-Wilensky E, et al. Reduced mortality rate in patients with severe traumatic brain injury treated with brain tissue oxygen monitoring. J Neurosurg 2005;103:80511.

23. Thompson HJ, Tkacs NC, Saatman KE, Raghupathi R, McIntosh TK. Hyperthermia following traumatic brain injury: a critical evaluation. Neurobiol Dis 2003;12:163-73. 